\title{
EXPLORATION OF TAX COMPLIANCE DETERMINATION ON MICRO, SMALL AND MEDIUM ENTERPRISE
}

\author{
Agus Supriyono*1), Intiyas Utami ${ }^{2)}$ and Ali Muktiyanto ${ }^{3)}$ \\ Indonesia Open University ${ }^{1)}$, Satya Wacana Christian University ${ }^{2}$, Indonesia Open University ${ }^{3)}$ \\ guspri.pajak@gmail.com ${ }^{l)}$,intiyas.utami@uksw.edu ${ }^{2)}$ and ali@ecampus.ut.ac.id ${ }^{3)}$
}

\begin{abstract}
The background of this research is the contribution of tax revenue from the Small Micro and Medium Enterprises (MSMEs) sector which is still less than the national tax revenue although the amount of tax revenue from the UMKM sector continues to grow. This condition occurs after the government issued special tax rates for MSMEs through Government Regulation Number 46 of 2013 and most recently amended through Government Regulation Number 23 of 2018. The sources of this research are the MSMEs taxpayers in Tegal City, Tegal Regency, and Brebes Regency which consist of industry players, store building owners, food stall owners, transportation service actors, workshop owners, gold shop owners, and fishing tool shop owners. This research was made using a qualitative research design with a qualitative descriptive approach. The conclusion obtained from this research is that MSMEs tax compliance is influenced by the determinants of the modernization of the taxation system (eSystem), the financial condition of taxpayers, financial records, service from tax officers, the level of tax awareness, transparency of information on the use of tax results, the level of understanding of taxpayers. Taxes, tax systems, tax sanctions, and annual tax return forms. The theoretical benefit of this research is that it can be used as a reference in the development of further research, increasing knowledge about the theory related to tax compliance and the factors that affect the level of compliance of MSMEs in carrying out their tax obligations. The practical benefit of this research is that it can provide input for the Government to design regulations that can be understood by all levels of society and supported by simple and applicable instruments. As well as being able to contribute to MSMEs so that they can participate in national development through fulfilling honest and open tax obligations.
\end{abstract}

Keywords: Tax; Tax Compliance; Micro Small Medium Enterprise; Taxpayers; Tax Office.

*Corresponding author

Email: guspri.pajak@gmail.com

DOI: https://doi.org/10.33369/j.akuntansi.11.1.33-52

\section{INTRODUCTION}

Tax is a source of state income that has a very important role in the survival of a nation. Tax revenue is the main pillar of state revenue. Micro, Small, and Medium Enterprises (MSMEs) have an important and strategic role in the wheels of the Indonesian economy. The contribution of MSMEs to Indonesia's Gross Domestic Product (GDP) is quite significant. The existence of MSMEs is strong because they are spread across the country and control about 99 percent of business activities in Indonesia, with more than 98 percent of them having the status of micro-enterprises. The productive sector of MSMEs can employ more than 107.6 million Indonesians (Nurfadilah, 2018).

Improving MSME tax compliance, the Government provides special rules regarding the calculation, deposit, and reporting of income tax payable. This is manifested by the issuance of Government Regulation Number 46 of 2013. Taxpayers who receive income from businesses with a gross turnover not exceeding IDR 4,800,000,000 in 1 (one) Tax Year are subject to Final Income Tax $(\mathrm{PPh})$ at a rate of one percent ( $1 \%)$ of gross circulation. This regulation was later amended by Government Regulation Number 23 of the Year 2018 by reducing the Final Income Tax rate to half a percent $(0.5 \%)$. 
The number of taxpayers from MSMEs is increasing and income tax revenue from the MSME sector shows an increasing trend. However, the tax contribution from MSMEs is still small compared to the total state revenue from taxes. MSMEs' tax revenue that has not been optimal is influenced by their level of compliance. This situation applies in almost all regions of Indonesia, including the City of Tegal, Tegal Regency, and Brebes Regency. The three areas in the Tegal Tax Office work area have various types of MSMEs run by their residents. However, the number of taxpayers who paid income tax from the MSMEs sector was only $33.47 \%$.

Most of the previous research on MSMEs taxpayer compliance was carried out during the validity period of Government Regulation Number 46 of 2013. Research by Ananda et al. (2015) stated that MSMEs tax compliance is influenced by the socialization of taxation, tax rates, and understanding of taxation. Taxpayer compliance to pay taxes is also influenced by the awareness of paying taxes and the quality of taxation services (Hardiningsih \& Yulianawati, 2011). Also, tax compliance can also be influenced by factors of distrust of the tax authorities (Friskianti \& Handayani, 2014). The special income tax rate from the MSMEs sector in Indonesia has a positive impact on the number of taxpayers and the amount of income tax revenue from the MSME sector. However, the income tax contribution from the MSME sector is still very small compared to the total state revenue from taxes (Sa'diya, Maulida Alfi Lofiana. Handayani, Siti Ragil. Effendy, 2016; Tjiali, 2015). It is recommended that entrepreneurs who have special characteristics such as MSMEs apply a final tax accounting treatment of $1 \%$ of their business turnover each month, rather than applying the general rate of 25\% (Diatmika, 2013).

However, there have not been many studies that analyze the factors that affect the level of compliance of taxpayers of MSMEs after the reduction in income tax rates from the MSME sector through Government Regulation Number 23 of 2018. Also, the determinants of compliance found in one study are different from one another. Several studies have also concluded different results regarding the effect of a factor on adherence. For example, research by Hardiningsih \& Yulianawati (2011) concluded that understanding tax regulations does not affect the willingness to pay taxes. However, the opposite results were obtained by (Imaniati, 2016) where the study concluded that the understanding of taxation had a positive and significant effect on the compliance of MSMEs taxpayers. Based on the description above, this research was conducted to examine the causes of low MSMEs taxpayer compliance by exploring the determinants of MSMEs taxpayer compliance.

This study aims to explore the determinants of tax compliance on MSMEs in the City of Tegal, Tegal Regency, and Brebes Regency. The theoretical benefits of this research are so that it can be a reference for students, teachers, and researchers in the development of further research, adding to the knowledge of theories related to tax compliance and the factors that affect the level of compliance of MSMEs taxpayers in fulfilling their tax obligations. Besides, this research has practical benefits to provide input for policymakers in the Government to design regulations and formulate policies that can be understood by all levels of society and supported by simple and applicable instruments. This research is also expected to contribute to MSMEs as input to be able to participate in state development through the fulfillment of honest and open tax obligations.

\section{RESEARCH METHODS}

This study used a qualitative descriptive research design with a case study type. The type of data used in this study is primary data obtained from interviews with informants to answer research questions. The data is information or opinion from sources regarding the reasons behind their compliance and non-compliance in fulfilling tax obligations as MSMEs. 
This research is located at the Tegal Tax Office. This research focuses on MSMEs who have been registered as taxpayers at the Tegal Tax Office and conducted consultations at the Tegal Tax Office from September $1^{\text {st }}$, 2019, to September 30, 2019. The source of information for this research is the taxpayers of MSMEs in the Tegal City, Tegal Regency, and Brebes Regency. The informants in the study consisted of various MSMEs including Pharmacy, Restaurant, Contractor, Salesman, Convection Industry, Store Building, Gas Station, Transportation Services, Welding Services, Rental Services, Motorcycle Shop, Gold Shop, and Event Organizer.

Data analysis methods in this research are data collection, data reduction, data analysis, data triangulation, data presentation, and conclusion drawing. Data analysis was carried out by transcribing the results of the interviews by organizing the results of the interviews and research question guides in the transcripts. Furthermore, the data from the interview transcripts on MSMEs are reduced. The data obtained is quite a lot and complex, therefore it is necessary to record it carefully and in detail. The results of the interview are then reviewed and then analyzed, interpreted, and narrated to explain the phenomenon of the causes of the low compliance of the MSMEs taxpayers. This stage is carried out by grouping the information based on the literature review and previous research results. The grouping of interview results and research question guidelines is carried out based on the determinants of tax compliance at MSMEs. The mapping of the determinants of tax compliance in MSMEs will also be examined based on 3 (three) types of human behavior considerations according to the Theory of Planned Behavior (TPB). Mapping of determinants of tax compliance in MSMEs is also carried out through a pyramid of taxpayers as suggested by the Organization for Economic Co-operation and Development (OECD) Center for Tax Policy and Administration (2004).

To check the validity of the data, this study conducted a data validity test through triangulation techniques. This study used source triangulation, technical triangulation, data triangulation, theory triangulation, and time triangulation. The next stage is to present the data and interpret the results of the data analysis. The next stage is to make conclusions and verify the data. Making conclusions or verification is carried out continuously. Making conclusions is an advanced analysis of data reduction and data presentation so that the data can be concluded. At this stage, the research still has the opportunity to receive input. Temporary conclusions can still be retested.

\section{RESULTS AND DISCUSSION}

\section{Analysis of Tax Compliance Determinants on MSMEs}

The MSMEs involved in this research are:

Table 1. List of Research Informants

\begin{tabular}{lll}
\hline No & Name & \multicolumn{1}{c}{ Business } \\
\hline 1 & CS & Pharmacy \\
\hline 2 & P & Rental Services \\
\hline 3 & RNA & Restaurant \\
\hline 4 & DUS & Contractor \\
\hline 5 & F & Salesman \\
\hline 6 & IS & Convection \\
\hline 7 & - & Store Building \\
\hline
\end{tabular}

\begin{tabular}{lll}
\hline No & Name & \multicolumn{1}{c}{ Business } \\
\hline 21 & TP & Contractor \\
\hline 22 & PS & Rental Services \\
\hline 23 & DF & Salesman \\
\hline 24 & HR & Salesman \\
\hline 25 & KW & Motorcycle Shop \\
\hline 26 & - & Contractor \\
\hline 27 & - & Salesman \\
\hline
\end{tabular}


Agus Supriyono, Intiyas Utami and Ali Muktiyanto

\begin{tabular}{lll}
\hline No & Name & \multicolumn{1}{c}{ Business } \\
\hline 8 & MS & Contractor \\
\hline 9 & BTK & Salesman \\
\hline 10 & - & Gas Station \\
\hline 11 & - & Store Building \\
\hline 12 & & Contractor \\
\hline 13 & RNA & Transportation Services \\
\hline 14 & S & Restaurant \\
\hline 15 & AW & - \\
\hline 16 & UW & Welding Services \\
\hline 17 & BS & Salesman \\
\hline 18 & AI & Restaurant \\
\hline 19 & ARK & Salesman \\
\hline 20 & N & Salesman \\
\hline
\end{tabular}

\begin{tabular}{lll}
\hline No & Name & \multicolumn{1}{c}{ Business } \\
\hline 28 & - & Store Building \\
\hline 29 & JA & Entrepreneur \\
\hline 30 & CSS & Salesman \\
\hline 31 & P & Store Building \\
\hline 32 & HAR & Gold Shop \\
\hline 33 & - & Salesman \\
\hline 34 & - & Salesman \\
\hline 35 & - & Salesman \\
\hline 36 & PAM & Event Organizer \\
\hline 37 & - & Contractor \\
\hline 38 & AI & Restaurant \\
\hline 39 & - & Salesman \\
\hline 40 & - & Contractor \\
\hline
\end{tabular}

The informants were taxpayers who consulted at the Tegal Tax Office from 1 September 2019 to 30 September 2019. This period was chosen because 1 (one) month earlier the Tegal Tax Office had supervised Taxpayers who had not reported Annual Tax. Return Year 2018. Tegal Tax Office issues a Warning Letter to immediately submit the Annual Tax Return, which must be responded to no later than 30 (thirty) days from the date of the Warning Letter. Taxpayer informants who came to the Tegal Tax Office during this period were chosen because they were late in submitting their Annual Tax Returns so that they could be asked about the constraints and factors that had caused their non-compliance in fulfilling their tax obligations.

This study also involved informants from the Tegal Tax Office consisting of 1 (one) implementer from the Extensification and Counseling Section, namely Mr. BYP and 1 (one) Account Representative from the Extensification and Counseling Section, namely Mr. HW. The reason for choosing informants from the Extensification and Counseling Section is that this section is directly related to the obligation of guidance, education, and counseling for new taxpayers. The Extensification and Counseling Section is also obliged to oversee the calculation, payment or deposit, and reporting of new taxpayers' tax obligations so that they know the obstacles of taxpayers in fulfilling their tax obligations from the moment they are registered as taxpayers.

The determinants of tax compliance obtained from this study are:

1. Modernization of the Taxation System (e-System)

To make it easier for taxpayers to fulfill their tax obligations, the Directorate General of Taxation has modernized modern tax administration that follows technological advances with e-system-based services such as e-Registration, e-SPT, e-Filing, and e-Billing. The application of this e-system is expected to improve the control and reporting mechanism which is more effective.

- e-Registration is a means of registering taxpayers and/or business reporting to be confirmed as VAT enterprises, changing data on taxpayers and/or VAT enterprises, moving taxpayers, eliminating tax ID numbers, and revoking VAT enterprises through the internet which is directly connected online with the Directorate General of Taxes (Director General of Taxes Regulation Number PER-02/PJ/2018). 
- electronic SPT (e-SPT) is a Tax Return submitted in the form of an electronic document. The e-SPT application provided by the DGT can be used by taxpayers to report the calculation and payment of taxes, tax objects and non-tax objects, assets, and liabilities following the provisions of applicable tax laws in the form of electronic documents (Director General of Taxes Regulation Number PER-01/PJ/2017).

- e-Filing is a method of submitting Tax Return through certain channels stipulated by the Director-General of Taxes. Submissions can be made online and in realtime via the internet on the website of the Directorate General of Taxes (www.pajak.go.id) or the provision of application services or application service providers (ASP) (Director General of Taxes Regulation Number PER-02/PJ/2019).

- e-Billing is a method issued by the Directorate General of Taxes to make electronic payments using a billing code to be paid through a perception bank or perception post. e-Billing makes the work process more concise because taxpayers do not need to bring a lot of documents to the bank to make tax deposits (Directorate General of Taxes Regulation Number PER-05/PJ/2017)

This determinant is mostly found in this study. The ease of tax administration by using this e-system is felt by some taxpayers, especially in the means of submitting, calculating, and paying taxes. Mr. CS (a pharmacy entrepreneur in Tegal City) expressed his opinion in the results of the interview as follows:

("..Thank God, (with the e-system) it is very easy. Especially e-billing, because I don't have to bother queuing at the tax office to pay taxes like before to fill out the tax payment slip.")

The same opinion was conveyed by Mr. P (director of a rental service company) who stated that:

(“...At first, I was shocked, because I can't pay taxes using the tax payment slip anymore, I have to use the billing code. But after a long time, I felt the benefits. It is more practical, you can make billing code from home, the payment can be via transfer.")

However, the application of the e-System is still not optimal because there are still many taxpayers who do not understand and recognize the e-System. As stated by Mr. Fadillah (trader) who has difficulty fulfilling his tax obligations because he has not received information about the use of the e-System for MSMEs Taxpayers.

("I have difficulty accessing it, because I live in a remote village (Cintamanik), so paying and reporting taxes is not as easy as expected. Socialization in the village is still lacking.")

So it can be concluded that on the determinants of the modernization of the taxation system (e-System), there is a positive response from MSMEs that can take advantage of technological developments to fulfill their tax obligations. However, there is a negative response from some for other MSMEs that cannot keep up with technological developments in fulfilling their tax obligations.

\section{Financial condition}

Financial condition is one of the factors that influence the compliance of MSME Taxpayers to comply with tax regulations. Financial condition is the company's financial capacity as reflected in the level of profitability and cash flow. MSMEs taxpayers with low profitability generally experience financial difficulties and tend to commit tax non-compliance. According to (Jayanto, 2010), this tax non-compliance is carried out to maintain cash flow. The 
low level of profitability resulted in their dishonesty in reporting the circulation of their business, either through non-compliance in paying taxes on time or in understating the amount of taxes that should be paid. This information was obtained from Mr. IS (owner of a convection business in Tegal) who stated that:

("I have not been able to comply with taxes due to unstable business. My profit was small, I spent all my salary on employees and my children's school needs. There is no leftover to pay taxes. That's why I haven't paid taxes for a long time.")

The good financial condition of taxpayers will motivate them to carry out financial planning practices so that they can streamline the allocation of funds. With financial planning, the tax burden can be minimized and does not violate existing tax regulations. Tax planning is needed to be able to control financial risks and fulfill tax obligations because the greater the profits earned by MSMEs, the greater the responsibilities or obligations that must be fulfilled to shareholders and the Government in the form of taxes. So it can be concluded that there is a positive response from MSMEs to the determinants of financial conditions in fulfilling their tax obligations.

\section{Financial records}

According to (Trihatmoko \& Mubaraq, 2020), a good understanding of accounting will make it easier for taxpayers to carry out their obligations. Accounting understanding relates to the ability to understand and understand the transaction process to become financial reports. Taxpayers can be said to have a good understanding if they can properly keep records. Taxpayers who understand this well have the intention to comply also increases. Financial records are the basis for every taxpayer to calculate their taxes. Financial Recording is a process of recording regularly carried out to collect financial data and information which includes assets, liabilities, capital, income, and expenses, as well as the total cost and delivery of goods or services, which is closed by compiling financial reports in the form of balance sheets and profit and loss statements.

Another determinant of tax compliance that was found was the absence of financial records. MSMEs do not keep records or books of their business results. There are also MSMEs whose financial reports are mixed with personal finances. This information was obtained from a store building owner in Tegal City who declined to be named:

("Our company has difficulty in making good financial reports according to accounting rules.”)

The results of the interview with Mr. MS also provide the same information, where MSMEs find it difficult to keep financial records because no special officers are handling financial problems:

("I do not have time to fulfill my tax obligations, I also find it difficult to keep financial records of gross turnover each month. The thing is I don't have staff, I take care of everything myself, while I don't have any basic knowledge in accounting or bookkeeping like that. Tax payments are usually made flat each month..")

With no financial records, it is difficult for MSMEs to calculate the taxes that must be paid. The tax calculation in the tax return is not based on correct bookkeeping and actual conditions. Financial recording for MSMEs is also useful for knowing financial health conditions as well as a prerequisite for obtaining banking access. So it can be concluded that there is a positive response from MSMEs to the determinants of financial records in fulfilling their tax obligations. 


\section{Perceptions of Tax Officer Services}

Another determinant that most commonly affects the compliance of MSMEs taxpayers is the perception of tax officer services. The motivation of MSMEs taxpayers in fulfilling their tax compliance is influenced by the quality of services provided by tax officers. Ritonga (2018) explains the Moral Tax Theory, namely the taxpayers' motivations that influence tax collection. One of them is the attitude of helping, providing services, and facilities for tax officers as well as officers and law enforcers who are independent, abiding by principles, and with high integrity. Taxpayers will respond positively to how tax officials treat them.

Based on the results of interviews with MSMEs, many stated that their non-compliance with tax obligations was caused by a lack of service from tax officers, especially the lack of socialization regarding tax obligations for MSMEs. As stated by Mr. BTK (trader from Brebes Regency) which stated that:

("I have not been able to comply with taxes because I still do not understand taxes. Increase the socialization for traders like us. Previously, when I made the tax ID number I was given a guide paper, but I couldn't read it. When I work, I forget.")

A similar statement was also made by a trader from Tegal Regency who declined to be named. He stated that:

("I had difficulty getting information about the new tax regulations which prevented the making of annual tax returns. It is better if the tax office should do more socialization to the public and appeal to the importance of tax awareness.")

Tax socialization to MSMEs in fulfilling their tax obligations is needed because taxpayers still face difficulties in calculating, paying, and reporting taxes. It is necessary to improve services from tax officers in terms of knowledge, skills, and other supporting facilities to support taxpayers in fulfilling their tax obligations. So it can be concluded that there is a positive response from MSMEs to the determinants of service perceptions of tax officers in fulfilling their tax obligations.

\section{Tax Awareness Level}

Taxpayer Awareness is a condition in which the Taxpayer knows, understands, and implements taxation provisions properly and voluntarily. The higher the level of taxpayer awareness, the better the understanding and implementation of tax obligations so that it can increase compliance (Muliari \& Setiawan, 2011). Taxpayers who have low awareness will tend not to carry out their tax obligations or violate applicable tax regulations. There are still many MSMEs that perceive taxes as a burden so they pay taxes compulsively. Some MSMEs admit that the initiative to register themselves as taxpayers through making tax ID numbers at tax service offices is not based on their awareness of the importance of taxes for development, but rather as a condition for obtaining credit loans from banks or cooperatives. This was stated by Mr. RNA who stated that:

("I made a tax ID number to open a restaurant in Jakarta.")

This is in line with the statement of Mr. F (trader) who stated that:

("I used to make a tax ID number as a condition for applying for credit to a bank, so I didn't voluntarily make a tax ID number.")

This perception results in low awareness of MSMEs in fulfilling their tax obligations. They are only obedient in making income tax payments in the early months after being registered, and not even a few who only make one payment, but after that, they do not pay any income tax or annual tax return. Tax officers need to generate positive perceptions of taxes in the eyes of the public by increasing public knowledge of taxation and by conducting tax education intensively and continuously. So that MSMEs taxpayers are expected to understand 
and realize the importance of paying taxes as a form of national cooperation in collecting funds for the benefit of government financing and national development. So it can be concluded that there is a positive influence from MSMEs on the determinants of the level of tax awareness in fulfilling their tax obligations

\section{Tax Result Utilization Information}

Tax knowledge is also related to information possessed by taxpayers regarding how tax money is used. As a form of reciprocity of fulfilling the obligation to pay taxes, taxpayers claim their rights in the form of information that is officially provided in a language that is easy to understand, according to the facts that are felt by the majority of the public and a detailed presentation of what tax money is used for. The inadequacy and accessibility of information on the use according to the needs and meaning of the taxpayer should be suspected as a factor that hinders the willingness of taxpayers to cooperate in paying taxes so far. Knowledge about the use of contributions and the provision of public goods affects the willingness to pay taxes (Hartner-Tiefenthaler et al., 2013).

Some MSMEs feel that they have not received information on the use of tax proceeds in a transparent, clear, and appropriate manner. As a statement made by a store building owner in Tegal City who stated:

("I don't agree that the tax proceeds have been used maximally for the people. I feel I don't get any benefits if I pay taxes. I also don't know what the tax results are, but our country is still in debt. I have a little objection to taxes. I know that taxes are used for state development, but now the news is that the electricity subsidy has been withdrawn, gasoline continues to rise. I was confused about where the tax money went.")

Responding to this, Mr. HW as the representative of the Tegal tax office informed that the Ministry of Finance has currently issued a report on the progress of state revenue and expenditure regularly in the KITA APBN Bulletin: Performance and Facts which is published regularly every month and can be accessed by all levels of society. However, due to a lack of information and socialization, the public is not widely aware of the APBN KITA Bulletin report. The inadequacy and accessibility of information on the use according to the needs and meaning of the taxpayer should be suspected as a factor that hinders the willingness of taxpayers to cooperate in paying taxes so far. So it can be concluded that there is a positive response from MSMEs to the determinants of information transparency on the use of tax results in fulfilling their tax obligations.

\section{Tax Understanding Level}

The lack of awareness of taxpayers in paying taxes cannot be separated from the factor of knowledge and understanding of taxation itself (Nugraheni \& Purwanto, 2015). Taxpayers who have good knowledge and understanding of tax regulations will fulfill their tax obligations consciously and voluntarily without any compulsion at all. Lack of understanding of taxation is indeed one of the main determinants that affect the non-compliance of MSMEs with their tax obligations. As the statement conveyed by Mr. IS (a convection entrepreneur) which states that:

("I don't understand about the obligations. I got a letter (warning letter) asking for tax reports, so I just know now. I have not fulfilled my tax obligations. Only paid once when I created the tax ID number.")

A similar statement was also made by Mr. BTK (a trader from Brebes District) who stated that: 
("I have not complied with taxes because I still do not understand taxes. I work in Jakarta, coming home at least two or three times a year. When I got home, I just got to take care of taxes. I don't know how to fill out an annual tax return.")

The majority of taxpayers do not understand tax laws properly, so they complain of having poor subjective knowledge, feel incompetent and helpless in tax matters, and feel constrained to seek tax officials' help. Barriers to MSMEs taxpayers are related to their level of understanding of taxation regarding tax regulation knowledge, lack of technical skills in using online services, and difficulty understanding tax forms that are considered complicated, it is important to consider tax authorities in educating taxpayers to have an understanding of taxes. Understanding taxation affects awareness and willingness to pay taxes properly. So it can be concluded that there is a positive response from MSMEs to the determinants of the level of understanding of taxation in fulfilling their tax obligations.

\section{Tax System}

The taxation system in effect in Indonesia is a self-assessment system, in which the taxpayer is given full trust by the government to calculate, pay, and self-report the tax owed following applicable tax regulations. According to Diamastuti (2018), there are many noncompliance by taxpayers because of this self-assessment system. There are still many taxpayers who do not know how to calculate their taxes even though they have a fairly high income. With the self-assessment system, the tax evasion action is deliberate. Taxpayers manipulate their financial reports, undermine the amount of income that must be received or create multiple financial records.

The implementation of the self-assessment system requires taxpayers to be active in carrying out their tax obligations. However, in practice, this given trust cannot be fully utilized by taxpayers. There are still many taxpayers who have difficulty independently calculating, paying, and reporting the tax owed. As stated by a contractor in Tegal Regency who stated the difficulty in calculating taxes according to the rules. The same thing was expressed by Mr. R (owner of a transportation service) who had difficulty paying and reporting the Annual Tax Return on time. Mrs. S (restaurant owner) stated that:

("Sometimes I forget the due date for paying taxes and sometimes the provider's network is having an error browsing the tax website.")

Income tax from the MSMEs sector which uses gross circulation as a basis for calculation is also complained of by some MSMEs taxpayers. This complaint arises because it does not consider business costs so that it tends to benefit taxpayers with a higher gross profit margin when compared to taxpayers with a smaller profit margin. As stated by Mr. AW who stated that:

("I feel the taxes charged to MSMEs are too high. I welcome the reduction in tax rates. But the rate of $0.5 \%$ (half percent) of gross turnover without paying attention to costs is in my opinion still unfair. We recommend that you base it from net turnover only.")

A similar statement was also made by Mr. Urip Widiyanto (owner of a welding services) who stated that:

("Net income should be the basis for calculating taxes, not gross income. My income is barely enough, so taxes are too burdensome.")

The solution for MSMEs taxpayers who object to the imposition of gross circulation as the basis for calculating income tax from the MSMEs sector has been fulfilled through PP 23 of 2018. This regulation provides an option for taxpayers to choose and not make the income 
tax scheme from the MSMEs sector an obligation. MSMEs taxpayers can choose to be subject to income tax at the general rate.

The implementation of the self-assessment system shows that it has not been running as expected or has been misused. This can be seen from the number of taxpayers whose taxpayers have difficulty in calculating, paying, and reporting payable tax independently, intentionally disobeying, and the low awareness of taxpayers, thus making taxpayers reluctant to pay taxes. There is a positive response from MSMEs to comply with the implementation of the selfassessment system in fulfilling their tax obligations. However, for some other MSMEs that are less or less compliant, there is a negative response to the implementation of the self-assessment system in fulfilling their tax obligations.

\section{Tax Sanctions}

According to Supriyati (2017) the legality set by the government, one of which is through the application of tax sanctions, affects taxpayer compliance. The imposition of sanctions on taxpayers can lead to the fulfillment of tax obligations by taxpayers to increase taxpayer compliance. Based on the results of the interview, MSMEs taxpayers have only fulfilled their tax payment and reporting obligations after receiving a warning letter and tax collection letter from the tax office. An example is a statement submitted by Mr. BS (trader from Brebes) regarding the imposition of sanctions:

("I just found out that there is a tax report (annual tax report) because I got a tax collection letter from here (Tegal tax office). Previously, the tax officer gave me an explanation (tax rights and obligations) when I registered the tax ID number, but I forgot.")

Some respondents honestly stated that the fulfillment of their tax obligations was done in order not to get tax sanctions or not to take any audit action by the tax authorities. As stated by Mr. ARK (trader) who stated that:

("I pay taxes just to be safe, I mean I feel safe when my tax matters are done. Not subject to sanctions and not subject to tax audits.")

Taxpayers fulfill their tax obligations after receiving tax sanctions because they think that tax sanctions will be more detrimental, the more disobedient, the greater the sanctions. Taxpayers will fulfill their tax obligations because they are afraid of the sanctions they will receive if they violate tax regulations. So it can be concluded that there is a positive response from MSMEs to the imposition of tax penalties in fulfilling their tax obligations.

\section{Annual Tax Return Form}

According to Nugraheni \& Purwanto (2015), the lack of awareness of taxpayers in paying taxes cannot be separated from factors of knowledge and understanding of taxation itself. One of the obstacles felt by MSMEs taxpayers related to their level of understanding of taxation is the difficulty in understanding tax forms that are considered complicated. After the enactment of special Income Tax rates for MSMEs, there are no derivative rules that specifically regulate the form of the Annual Tax Return form for MSMEs Taxpayers. Thus, the Annual Tax Return for MSMEs taxpayers will still use the Annual Tax Return form that is generally accepted like other taxpayers.

Annual Tax Return Form 1770, consists of 9 sheets including attachments, while Annual Tax Return Form 1771 consists of 25 sheets including special attachments. The number of sheets that must be filled is an obstacle for MSMEs taxpayers in fulfilling their tax reporting. As stated by Mrs. N (child kebaya seller) who stated that:

("I have difficulty filling out the Annual Tax Return which in my opinion is still too complicated. If possible, there is a simplification of the Annual Tax Return form specifically 
for MSMEs taxpayers and if you can make a Tax Return application that can be opened via cellphone, there is no need to fill in via installing the application.")

The Directorate General of Taxes has provided an alternative to reporting Annual Tax Return via the internet or e-Filing for those who have difficulty filling in Annual Tax Return manually. However, not many MSMEs taxpayers can take advantage of the online Annual Tax Return reporting. For this reason, it is necessary to simplify the form of the Annual Tax Return specifically for MSMEs taxpayers. So it can be concluded that there is a positive response from MSMEs to the determinants of the Annual Tax Return form in fulfilling their tax obligations.

\section{Analysis of Theory of Planned Behavior (TPB) on the Determinants of MSMEs Tax Compliance}

Taxpayer compliance is related to the applicable tax collection system. As is known, the taxation system in Indonesia adopts a self-assessment system. According to Diamastuti (2018), many non-compliance made by the taxpayer does not yet know how to calculate their taxes even though they have a fairly high income. Kirchler \& Wahl (2010) state that tax compliance is carried out because of voluntary compliance and enforced compliance. Taxpayers 'obedient or disobedient behavior in fulfilling their tax obligations is influenced by the taxpayers' intention (Hidayat \& Nugroho, 2010). If the taxpayer has the intention to comply with their tax obligations, tax compliance behavior will occur. This action is relevant to Ajzen's Theory of Planned Behavior (TPB). Theory of Planned Behavior (TPB) is a theory for predicting behaviors that are completely not under individual control.

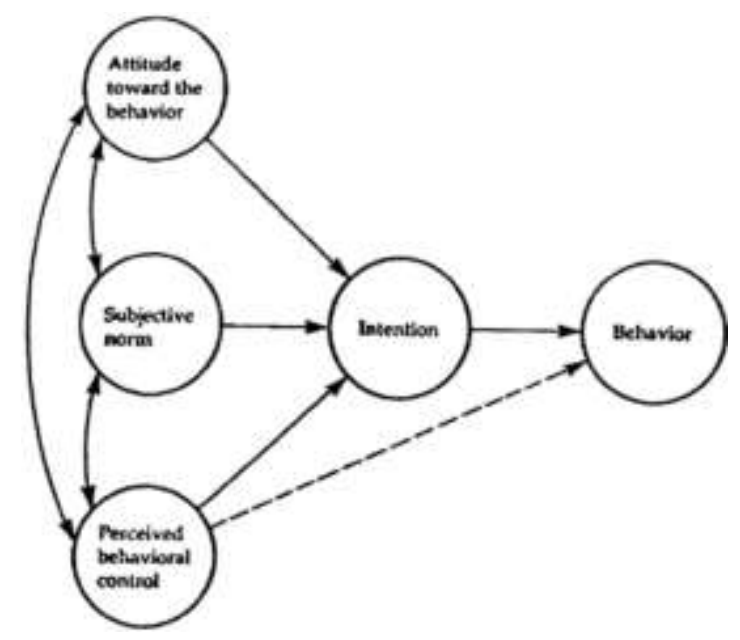

\footnotetext{
Picture 1 Model of Theory of Planned Behavior (TPB)

(Source: Ajzen, I. (1991). The theory of planned behavior.

Organizational Behavior and Human Decision Processes, 50, p.182)
}

Ajzen argues that based on the Theory of Planned Behavior (TPB), explaining the behavior of individuals arises because the individual intended to behave and the individual's intention is caused by several internal and external factors of the individual. The intention to behave is influenced by three factors, namely: (1) Behavioral beliefs, namely beliefs strength and outcome evaluation. Behavioral beliefs produce attitudes toward good or bad behavior; (2) Normative beliefs, namely normative beliefs and motivation to comply. Normative beliefs result in perceived social pressure or subjective norms; and (3) control beliefs, namely beliefs about the existence of factors that can facilitate or inhibit the behavior to be displayed (control beliefs) and perceptions about how strong these factors are (perceived power). Control beliefs lead to perceived behavioral control. 
The results of this study, variable attitude towards tax compliance (behavioral belief), and perceived behavior control (control belief) can strengthen taxpayers' intentions and encourage MSMEs taxpayers to comply with their tax obligations. Meanwhile, there is no subjective norm variable (normative belief) that affects the intention of MSMEs taxpayers to fulfill their tax obligations.

Exploration of attitudes towards MSMEs tax compliance is reflected in the level of tax awareness and rational attitudes. A high level of tax awareness and a rational attitude that is more concerned with the public interest has a positive effect on the intention to comply with taxes. Another factor is the perceived behavioral control variable, which consists of the level of capability (self-efficacy) and the level of control over behavior (controllability). The level of capability is reflected in the ability of MSMEs taxpayers to understand tax regulations, the ability to keep up with technological developments through the modernization of the taxation system (e-System), the ability to achieve good financial conditions, and the ability to keep good financial records.

Subjective norms are not a factor affecting the taxpayer's intention to comply or not comply with tax provisions. These results are obtained from the results of interviews and the results of filling out questionnaires which state that MSMEs will still pay taxes even though the community around them does not pay taxes and the intention of MSMEs to report taxes correctly is not because of community recommendations in the environment, but because of their initiatives. Even though they realize that the people in their neighborhood have not reported taxes correctly, this does not affect their decision to comply or not comply with their tax obligations. As stated by a director of the contracting company who stated that:

("I obey taxes as much as possible, even though many people around me have not paid taxes in an orderly manner, many people have high incomes but don't have a tax ID number.")

The intention of the MSMEs taxpayers to become compliant behavior depends on the actual control. This means that a person's intention to not comply with taxes can manifest into non-compliance behavior due to lack of supervision by the tax officer. If the supervisory system carried out by the tax officer is good, the controllability will drop quickly and the person will display a behavior that is different from what was intended.

\section{MSMEs Taxpayer Behavior Mapping and Treatment}

Mapping the behavior of taxpayers and their treatment can be done through the pyramid of the taxpayer's group as suggested by the Organisation For Economic Co-Operation And Development /OECD, (2004). The compliance behavior of taxpayers varies so that each particular level of compliance can be treated with a certain compliance strategy. This pyramid divides the taxpayer compliance level behavior into 4 levels with 4 types of compliance strategies that can be carried out by tax authorities. At the most ideal level is when the taxpayer already has very high awareness in carrying out their tax obligations (willing to do the right things), so that the tax authorities compliance strategy must continue to provide the best facilities and services. 


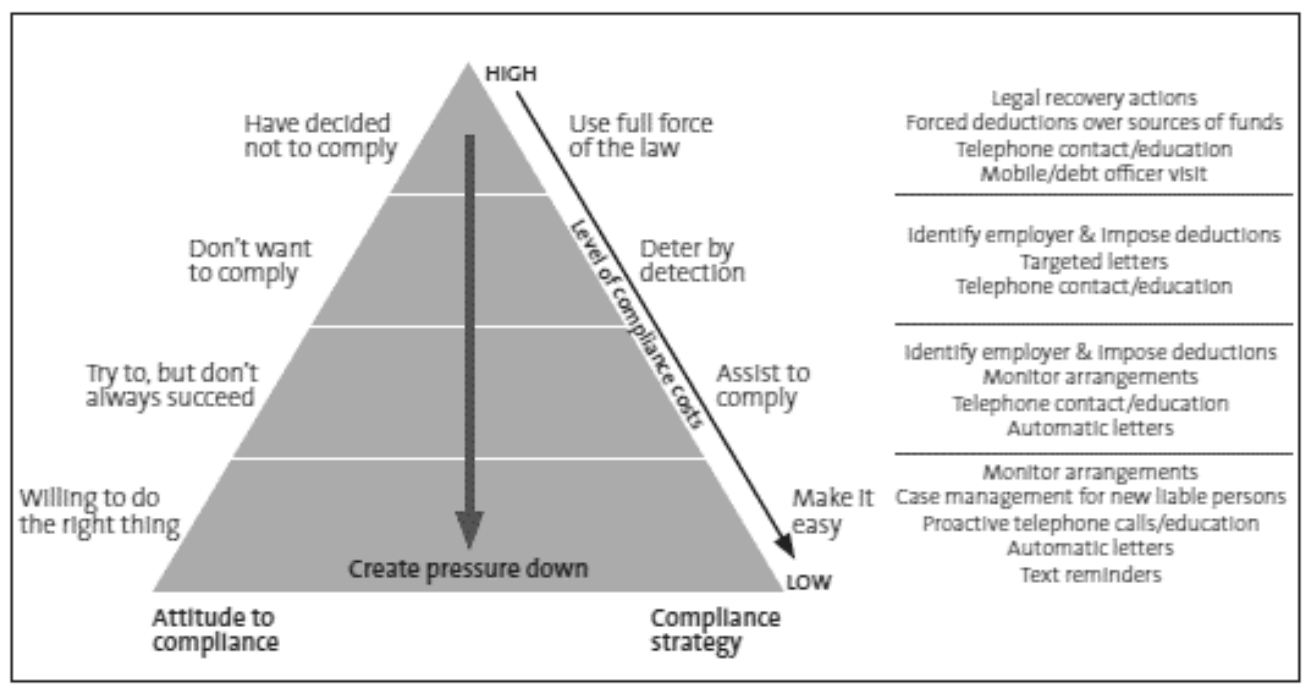

Picture 2 the pyramid of the taxpayer's group

Source: Organisation For Economic Co-Operation and Development (OECD). (2004). Compliance Risk Management: Managing and Improving Tax Compliance, p.41

Analysis of the grouping of MSMEs Taxpayers in the City of Tegal, Tegal Regency, and Brebes Regency based on group mapping can be carried out through the Taxpayer group pyramid by the Organization for Economic Co-operation and Development (OECD) Center for Tax Policy and Administration (2004) as follows:

1) Taxpayers who have very high awareness in carrying out their tax obligations properly (willing to do the right things)

There were only a few correspondents who belonged to this group. For this group of taxpayers, tax officers need to create all facilities intended to make it easier for taxpayers to fulfill their tax obligations. The form of this facility can be in the form of simplifying all forms of requests, prioritizing frontline services to providing an electronic-based service platform created to pamper taxpayers in paying their taxes. One of the facilities or special treatment for compliant Taxpayers by the Tegal Tax Office is the ease of applying for an Advance Tax Overpayment Refund Decree.

2) Taxpayers who try to take advantage of opportunities to avoid taxes even though they are not always successful (try but do not always succeed)

Many taxpayers have the desire to comply with taxes. However, this desire does not always produce positive results, especially due to constraints, such as the inability to carry out financial records or the inability to take advantage of the e-Billing, e-Filing facilities, which causes them to be late in making payments or reporting the Annual Tax Return. This type of group does not have consistent behavior, that is, sometimes obedient and sometimes disobedient. For Taxpayers in this group, Tax Officers need to provide services and need to get guidance and socialization to eliminate the obstacles they face. This socialization is an effort to remember and increase awareness of the tax obligations of taxpayers. Based on the information obtained from the Tegal Tax Office, this step has been implemented at the Tegal Tax Office in the form of sending reminder messages through short message service technology, continuous socialization, more intense public communication, and dialogues with associations, associations, and other stakeholders.

3) Taxpayers do not comply, that is, they are not willing to comply with the applicable regulations (don't want to comply)

Some Taxpayers tend to be non-compliant but can turn into compliance if their noncompliance is detected by the Tax Officers. Taxpayers in this group always actively avoid 
fulfilling their obligations for different reasons. For this group, Tax Officers need to emphasize the detection of mistakes made by taxpayers and it is necessary to make efforts to prevent mistakes so that mistakes are not repeated. Based on information obtained from the Tegal Tax Office, this action has been carried out by the Tegal Tax Office through monitoring of tax payments and reporting carried out by the Account Representative and through tax audits conducted by the Tax Auditor. For taxpayers who try not to comply, the Account Representative will send a Request for Explanation of Data and/or Information (SP2DK), an appeal letter to a warning letter to the taxpayer to fulfill their tax obligations. If the taxpayer has not yet complied, it will be forwarded to a tax audit by the Tax Auditor.

4) Taxpayers who are completely unwilling to fulfill their tax obligations

There were no taxpayers who had decided not to comply. This is because the interview was conducted at the Tegal Tax Office. Taxpayers who come to the Tegal Tax Office are those who want to fulfill their tax obligations, either on their awareness or because they get a warning from the Tax Officers. Based on information obtained from the Tegal Tax Office, this group can be met at the work location during the visit. There are still many MSMEs that have not been detected yet have a tax ID number and have not had the awareness to report their business activities. For this group, Tax Officers can use every effort to force them to comply, including the imposition of criminal tax penalties. Tax Officers need to enforce firm action in the form of imposition of penalties, investigations, prosecution in court, and other legal treatment so that they are deterred and do not become bad role models for other taxpayers.

According to Hidayat \& Nugroho (2010), the high level of complexity of tax regulations can lead to tax non-compliance behavior. Tax officers need to differentiate the treatment of MSMEs taxpayers according to their compliance group. Do not let compliant taxpayers be treated like non-compliant taxpayers. Do not let taxpayers who do not comply or even have been outside the tax administration system not take any tax law enforcement action. The larger the obedient taxpayer group is expected to be able to influence society's behavior as a whole. They are expected to be able to exert greater pressure on taxpayers who are not obedient and deliberately evasive, and then change their behavior to become compliant taxpayers.

\section{CONCLUSIONS AND SUGGESTION}

\section{Conclusions}

It can be concluded that the determinants of tax compliance on MSMEs in the City of Tegal, Tegal Regency, and Brebes Regency which can be explored from this research are: Modernization of the tax system (e-System), The financial condition of the Taxpayer, Financial records; Services from tax officers, Tax awareness level, Transparency of information on the utilization of tax results, Taxpayer's level of understanding of taxation, The tax system, Tax sanctions, and Annual Tax Return Form. In general, there is a positive response from MSMEs to each of the determinants in fulfilling their tax obligations. What gave a negative response were MSMEs that could not keep up with technological developments on the determinants of the modernization of the taxation system (e-System) and SMEs who did not or did not comply with the implementation of the self-assessment system in fulfilling their tax obligations. The most dominating and often found determinants in research are the determinants of the modernization of the tax system (e-System) and the services of the Tax Officers.

\section{Suggestion}

Further research may use data collection methods that are more likely to produce a higher response rate, for example by direct interview or by telephone at the taxpayer's business 
location. Further research can explore the determinants of tax compliance on MSMEs in terms of tax officers. The government is expected to be able to design tax systems and regulations that can be understood by all levels of society and supported by simple and applicable instruments and supported by socialization to all levels of society. The Tax Office is expected to provide a different pattern of guidance and treatment for MSMEs taxpayers according to their compliance group. MSMEs are expected to participate in the development of the country through the fulfillment of honest and open tax obligations. Obedient taxpayers are expected to be able to set an example for the people who are not obedient and deliberately avoid so that they can change their behavior to become obedient taxpayers.

\section{REFERENCES}

Ananda, P. R. D., Kumadji, S., \& Husaini, A. (2015). Pengaruh Sosialisasi Perpajakan, Tarif Pajak, dan Pemahaman Perpajakan Terhadap Kepatuhan Wajib Pajak (Studi pada UMKM yang Terdaftar sebagai Wajib Pajak di Kantor Pelayanan Pajak Pratama Batu). Jurnal Perpajakan (JEJAK), 151(2), 10-17. https://doi.org/10.1145/3132847.3132886.

Diamastuti, E. (2018). Ke (Tidak) Patuhan Wajib Pajak: Potret Self Assessment System. EKUITAS (Jurnal Ekonomi Dan Keuangan), 20(3), 280-304. https://doi.org/10.24034/j25485024.y2016.v20.i3.52.

Diatmika, I. P. G. (2013). Penerapan Akuntansi Pajak Atas PP No. 46 Tahun 2013 Tentang PPh Atas Penghasilan Dari Usaha Wajib Pajak Yang Memiliki Peredaran Bruto Tertentu. Jurnal Akuntansi Profesi, 3(46), 113-121.

Directorate General of Taxation. (2017a). Peraturan Direktur Jenderal Pajak Nomor PER01/PJ/2017 tentang Penyampaian Surat Pemberitahuan Elektronik.

(2017b). Peraturan Direktur Jenderal Pajak Nomor PER05/PJ/2017 tentang Pembayaran Pajak Secara Elektronik.

. (2018). Peraturan Direktorat Jenderal Pajak Nomor PER02/PJ/2018 tentang Perubahan Kedua Atas Peraturan Dirjen Pajak Nomor Per20/Pj/2013 Tentang Tata Cara Pendaftaran Dan Pemberian Nomor Pokok Wajib Pajak, Pelaporan Usaha Dan Pengukuhan Pengusaha Kena Pajak.

(2019). Peraturan Direktorat Jenderal Pajak Nomor PER02/PJ/2019. In Pajak.go.id. https://pajak.go.id/sites/default/files/2019-03/PER 32.PJ_.2015.pdf

Friskianti, Y., \& Handayani, B. D. (2014). Pengaruh Self Assessment System, Keadilan, Teknologi Perpajakan, Dan Ketidakpercayaan Kepada Pihak Fiskus Terhadap Tindakan Tax Evasion. 3(4), 457-465.

Government Regulations. (2013). Peraturan Pemerintah Nomor 46 Tahun 2013 tentang Pajak Penghasilan atas Penghasilan dari Usaha yang Diterima atau Diperoleh Wajib Pajak yang Memiliki Peredaran Bruto Tertentu. Jakarta

Government Regulations. (2018). Peraturan Pemerintah Nomor 23 Tahun 2018 tentang Pajak 


\section{Penghasilan atas Penghasilan dari Usaha yang Diterima atau Diperoleh Wajib Pajak yang Memiliki Peredaran Bruto Tertentu. Jakarta}

Hardiningsih, P., \& Yulianawati, N. (2011). Faktor-Faktor Yang Mempengaruhi Kemauan Membayar Pajak. Dinamika Keuangan Dan Perbankan, 3(1), 126-142.

Hartner-Tiefenthaler, M., Rechberger, S., \& Kirchler, E. (2013). Justice perceptions and cooperation of citizens with the tax-authorities: The group engagement model of cooperation. Citizenship Teaching \& Learning, 8(2), 179-193. https://doi.org/10.1386/ctl.8.2.179_1

Hidayat, W., \& Nugroho, A. A. (2010). Studi Empiris Theory of Planned Behavior dan Pengaruh Kewajiban Moral pada Perilaku Ketidakpatuhan Pajak Wajib Pajak Orang Pribadi. Jurnal Akuntanso Dan Keuangan, 12(2), 82-93. https://doi.org/10.1097/00042737-200205000-00005

Imaniati, Z. Z. (2016). Pengaruh Persepsi Wajib Pajak Tentang Penerapan Kecil , Dan Menengah Di Kota Yogyakarta. E Biling Jurnal Nominal, V(46), 1-13.

Jayanto, P. Y. (2010). Faktor-Faktor Ketidakpatuhan Wajib Pajak. Jurnal Dinamika Manajemen, 2(1), 48-61. https://doi.org/10.15294/jdm.v2i1.2487

Kirchler, E., \& Wahl, I. (2010). Tax compliance inventory TAX-I: Designing an inventory for surveys of tax compliance. Journal of Economic Psychology, 31(3), 331-346. https://doi.org/10.1016/j.joep.2010.01.002

Muliari, N. K., \& Setiawan, P. E. (2011). Pengaruh persepsi tentang sanksi perpajakan dan kesadaran wajib pajak pada kepatuhan pelaporan wajib pajak orang pribadi di kantor pelayanan pajak pratama denpasar timur. Jurnal Ilmiah Akuntansi Dan Bisnis, 6(1), 1-23.

Nugraheni, A. D., \& Purwanto, A. (2015). Faktor-faktor yang Mempengaruhi Kepatuhan Wajib Pajak Orang Pribadi (Studi Empiris Pada Wajib Pajak di Kota Magelang). Diponegoro Journal of Accounting2, 4(3), 568-581. https://ejournal3.undip.ac.id/index.php/accounting/article/view/17031

Nurfadilah, P. S. (2018). UMKM Матри Dongkrak Pertumbuhan Ekonomi. Https://Ekonomi.Kompas.Com.

https://ekonomi.kompas.com/read/2018/07/10/200246326/umkm-mampu-dongkrakpertumbuhan-ekonomi.

Organization For Economic Co-Operation And Development (OECD). (2004). Compliance Risk Management: Managing and Improving Tax Compliance. Centre for Tax Policy and Administration (CTPA), October, Hal: $1-73$. https://www.oecd.org/tax/administration/33818656.pdf

Ritonga, A. A. (2018). Pengantar Ilmu Hukum Pajak \& Perpajakan Indonesia. Pustaka El Manar.

Sa'diya, Maulida Alfi Lofiana. Handayani, Siti Ragil. Effendy, I. (2016). Analisis Penerapan 
Peraturan Pemerintah Nomor 46 Tahun 2013 untuk Wajib Pajak yang Memiliki Peredaran Bruto Tertentu (Studi Pada KPP Pratama Malang Utara). Jurnal Perpajakan (JEJAK), $10(1), 1-7$.

Supriyati. (2017). Tax Compliance Dan Tax Evasion: Tantangan Demokratisasi Wajib Pajak. Jurnal ASET (Akuntansi Riset), 9(2), 59. https://doi.org/10.17509/jaset.v9i2.9218

Tjiali, W. (2015). Analisis Penerapan Peraturan Pemerintah Nomor 46 Tahun 2013 Terhadap Terhadap Pertumbuhan Jumlah Wajib Pajak Dan Penerimaan Pph Pasal Analysis of Application Government Regulationnumber46Year2013 At Growth of. Jurnal EMBA, 3(4), 369-376.

Trihatmoko, H., \& Mubaraq, M. R. (2020). Pengaruh Pemahaman Akuntansi dan Pemahaman Perpajakan terhadap Kepatuhan Wajib Pajak pada KPP Pratama MAdiun. E-Jurnal Akuntansi, 30(9), 2231-2243. https://doi.org/10.24843/EJA.2020.v30.i09.p05

\section{APPENDIX}

Mr. CS (a pharmacy entrepreneur in Tegal City) expressed his opinion in the results of the interview as follows:

“...Alhamdulillah, (dengan adanya e-system) sangat memudahkan. Terutama e-billing, karena saya tidak perlu repot antri ke kantor pajak buat bayar pajak kaya dulu buat ngambil...ngisi SSP (Surat Setoran Pajak)."

("..Thank God, (with the e-system) it is very easy. Especially e-billing, because I don't have to bother queuing at the tax office to pay taxes like before to fill out the tax payment slip.")

The same opinion was conveyed by Mr. P (director of a rental service company) who stated that:

“...Dulu awalnya sempet kaget, soalnya udah ga bisa bayar pajak pake SSP (Surat Setoran Pajak) lagi, harus pake kode billing. Tapi lama-lama saya rasakan manfaatnya. Malah lebih praktis, bisa bikin (kode) billing dari rumah, bayarnya bisa transfer."

("...At first, I was shocked because I can't pay taxes using the tax payment slip anymore, I have to use the billing code. But after a long time, I felt the benefits. It is more practical, you can make billing code from home, the payment can be via transfer.")

As stated by Mr. Fadillah (trader) who has difficulty fulfilling his tax obligations because he has not received information about the use of the e-System for MSMEs Taxpayers.

"Kesulitan saya di akses, karena saya hidup di desa terpencil (Cintamanik), jadi untuk membayar dan melaporkan pajak tidak semudah yang diharapkan. Sosialisasi di desa masih sangat kurang."

("I have difficulty accessing it, because I live in a remote village (Cintamanik), so paying and reporting taxes is not as easy as expected. Socialization in the village is still lacking.")

This information was obtained from Mr. IS (owner of a convection business in Tegal) who stated that:

"(Belum bisa patuh pajak) karena usaha yang belum stabil. Untungnya ga seberapa, habis buat nggaji karyawan sama kebutuhan anak sekolah. Itu udah ngepas, ga ada sisa buat pajak. Makanya udah lama ga bayar pajak." 
("I have not been able to comply with taxes due to unstable business. My profit was small, I spent all my salary on employees and my children's school needs. There is no leftover to pay taxes. That's why I haven't paid taxes for a long time.”)

This information was obtained from a store building owner in Tegal City who declined to be named:

"Perusahaan kami kesulitan dalam membuat laporan keuangan yang baik sesuai dengan aturan akuntansi."

("Our company has difficulty in making good financial reports according to accounting rules.")

Mr. MS also provide the same information, where MSMEs find it difficult to keep financial records because no special officers are handling financial problems:

"Di samping masalah waktu luang yang kurang untuk ngurus pajak, saya juga kesulitan untuk melakukan pencatatan omset bruto tiap bulan. Soalnya saya ga pake staf, semuanya saya urus sendiri, sedangkan saya ga punya basic ilmu di akuntansi atau pembukuan kayak gitu. Buat bayar pajak omsetnya dikira-kira aja, biasanya dibikin rata tiap bulan."

("I do not have time to fulfill my tax obligations, I also find it difficult to keep financial records of gross turnover each month. The thing is I don't have staff, I take care of everything myself, while I don't have any basic knowledge in accounting or bookkeeping like that. Tax payments are usually made flat each month..")

As stated by Mr. BTK (trader from Brebes Regency) which stated that:

"Saya belum bisa patuh pajak soalnya masih kurang paham pajak. Perbanyak sosialisasi buat pedagang seperti kami. Dulu pas bikin NPWP sudah dikasih kertas panduan, cuman ga sempet baca. Kalau udah kerja jadi lupa."

("I have not been able to comply with taxes because I still do not understand taxes. Increase the socialization for traders like us. Previously, when I made the tax ID number I was given a guide paper, but I couldn't read it. When I work, I forget.")

A similar statement was also made by a trader from Tegal Regency who declined to be named. He stated that:

"Saya kesulitan mendapatkan informasi tentang aturan pajak yang baru sehingga menghambat pembuatan SPT Tahunan. Sebaiknya kantor pajak lebih memperbanyak soialisasi kepada masyarakat luas dan menghimbau tentang pentingnya sadar pajak." ("I had difficulty getting information about the new tax regulations which prevented the making of annual tax returns. It is better if the tax office should do more socialization to the public and appeal to the importance of tax awareness.")

This was stated by Mr. RNA who stated that:

"Saya bikin NPWP buat buka warung di Jakarta."

("I made a tax ID number to open a restaurant in Jakarta.")

This is in line with the statement of Mr. F (trader) who stated that:

"Saya dulu bikin NPWP buat syarat pengajuan kredit ke bank, jadi ga secara sukarela bikin NPWP." 
("I used to make a tax ID number as a condition for applying for credit to a bank, so I didn't voluntarily make a tax ID number.")

As a statement made by a store building owner in Tegal City who stated that:

"Saya kurang setuju kalau hasil pajak sudah dipakai secara maksimal untuk rakyat. Saya merasa saya tidak mendapatkan keuntungan kalau saya sudah bayar pajak. Hasil pajaknya juga saya ga tahu untuk apa saja, lha negara kita masih utang terus. Saya sebenarnya agak keberatan dengan pajak. Saya tahu kalau pajak dipakai buat (me)mbangun negara, tapi sekarang kan beritanya subsidi listrik dicabut, bensin naik terus. Saya jadi bingung uang pajak larinya ke mana."

("I don't agree that the tax proceeds have been used maximally for the people. I feel I don't get any benefits if I pay taxes. I also don't know what the tax results are, but our country is still in debt. I have a little objection to taxes. I know that taxes are used for state development, but now the news is that the electricity subsidy has been withdrawn, gasoline continues to rise. I was confused about where the tax money went.")

As the statement conveyed by Mr. IS (a convection entrepreneur) which states that:

"Soal kewajibannya ya saya ga paham. Saya dapat surat (Surat Teguran) suruh laporan pajak makanya baru tahu sekarang. Selama ini ya belum tertib bayarnya. Baru bayar sekali pas bikin NPWP."

("I don't understand about the obligations. I got a letter (warning letter) asking for tax reports, so I just know now. I have not fulfilled my tax obligations. Only paid once when I created the tax ID number.")

Mr. BTK (a trader from Brebes District) who stated that:

"Saya belum bisa patuh pajak soalnya masih kurang paham pajak. Kerja di Jakarta, pulang palingan setahun dua tiga kali. Pas pulang gini baru sempet ngurus pajak. SPTnya juga ga tau cara ngisinya."

("I have not complied with taxes because I still do not understand taxes. I work in Jakarta, coming home at least two or three times a year. When I got home, I just got to take care of taxes. I don't know how to fill out an annual tax return.')

Mrs. S (restaurant owner) stated that:

"Terkadang lupa tanggal batas akhir pembayaran pajak dan terkadang jaringan provider sedang error untuk browsing ke website pajak."

("Sometimes I forget the due date for paying taxes and sometimes the provider's network is having an error browsing the tax website.")

As stated by Mr. AW who stated that:

"Saya merasa pajak yang dibebankan ke pelaku UMKM terlalu tinggi. Saya sambut baik ada penurunan tarif pajaknya. Tapi tarif 0,5\% (setengah persen) dari omset kotor tanpa memperhatikan biaya itu menurut saya masih ga adil. Sebaiknya dasarnya dari omset bersih saja."

("I feel the taxes charged to MSMEs are too high. I welcome the reduction in tax rates. But the rate of $0.5 \%$ (half percent) of gross turnover without paying attention to costs is in my opinion still unfair. We recommend that you base it from net turnover only.")

Mr. Urip Widiyanto (owner of a welding services) stated that: 
"Harusnya yang dijadikan dasar ngitung pajak itu penghasilan bersih, jangan penghasilan kotor. Pendapatan saya pas-pasan jadi pajak terlalu memberatkan."

("Net income should be the basis for calculating taxes, not gross income. My income is barely enough, so taxes are too burdensome.")

Mr. BS (trader from Brebes) regarding the imposition of sanctions:

"Ini saya baru tahu kalau ada laporan pajak (SPT Tahunan) ya gara-gara dapat surat (Surat Tagihan Pajak) dari sini (KPP Pratama Tegal). Dulu udah dikasih penjelasan (hak dan kewajiban perpajakan) pas daftar NPWP sama petugasnya, tapi lupa."

("I just found out that there is a tax report (annual tax report) because I got a tax collection letter from here (Tegal tax office). Previously, the tax officer gave me an explanation (tax rights and obligations) when I registered the tax ID number, but I forgot.")

As stated by Mr. ARK (trader) who stated that:

"Saya membayar pajak biar aman saja, maksudnya saya merasa aman kalau sudah beres urusan pajaknya. Ga kena denda. Ga diperika."

("I pay taxes just to be safe, I mean I feel safe when my tax matters are done. Not subject to sanctions and not subject to tax audits.")

As stated by Mrs. N (child kebaya seller) who stated that:

"Saya mengalami kesulitan mengenai bentuk dan pengisian SPT yang menurut saya masih terlalu rumit. Kalau bisa ada penyederhanaan bentuk formulir SPT Tahunan khusus untuk WP pelaku UMKM dan kalau bisa dibuat aplikasi SPT yang bisa dibuka lewat HP, ga perlu ngisi lewat nginstall aplikasi."

("I have difficulty filling out the Annual Tax Return which in my opinion is still too complicated. If possible, there is a simplification of the Annual Tax Return form specifically for MSMEs taxpayers and if you can make a Tax Return application that can be opened via cellphone, there is no need to fill in via installing the application.")

As stated by a director of the contracting company who stated that:

"Saya sebisa mungkin patuh pajak, walau menurut saya masyarakat di sekitar saya banyak yang belum tertib pajak, banyak yang mampu tapi ga punya NPWP (Nomor Pokok Wajib Pajak)."

("I obey taxes as much as possible, even though many people around me have not paid taxes in an orderly manner, many people have high incomes but don't have a tax ID number.") 